Volume: 7

Nomor: 1

Bulan: Februari

Tahun: 2021

\title{
Efektivitas UU Nomor 33 Tahun 2014 tentang Jaminan Produk Halal (JPH) Terhadap Sadar Halal Para Pelaku UMKM di Kota Gorontalo
}

\author{
Yudin Yunus \\ Universitas Ichsan Gorontalalo \\ Pos-el: yudinhamzahyunus@gmail.com
}

DOI: 10.32884/ideas.v7i1.326

\begin{abstract}
Abstrak
Kesadaran para pelaku UMKM di Kota Gorontalo masih sangat kurang mengenai jaminan halal suatu produk terutama mengenai sertifikasi halal. Berdasarkan hal tersebut maka penelitian ini bertujuan untuk untuk mengetahui dan menganalisis efektifitas tentang jaminan produk halal terhadap sadar halal para pelaku usaha mikro kecil dan menengah di Kota Gorontalo. Metode penelitian yang digunakan dalam penelitian ini adalah penelitian hukum empiris, penelitian terhadap identifikasi hukum (tidak tertulis) dan penelitian terhadap efektifitas hukum. Hasil penelitian ini menunjukkan bahwa kurangnya kesadaran masyarakat Kota Gorontalo yang belum mengerti tentang sertifikasi halal. Hal ini juga tidak didukung dengan pengawasan pemerintah yang efektif dari proses sosialisasi pemberian sanksi sampai dengan sekarang, sehingga membuat pelaku usaha khususnya yang ada di Kota Gorontalo meremehkan hal itu.
\end{abstract}

\section{Kata Kunci}

Efektifitas, undang-undang, produk halal

\section{Abstract}

The awareness of UMKM players in Gorontalo City is still lacking regarding the halal guarantee of a product, in this case it is issued in the halal certification. Based on this, this study aims to determine and analyze the effectiveness of Halal Product Guarantee for halal awareness of micro, small and medium enterprises in Gorontalo City. The research method used in this research is empirical legal research, research on legal identification (unwritten) and research on legal effectiveness. The results of this study indicate that the lack of awareness of the people of Gorontalo city who do not understand about halal certification. This has also not been supported by effective government supervision of the socialization process for sanctions until now, thus making business actors, especially those in the city of Gorontalo, underestimate this.

\section{Keywords}

effectiveness, law, halal products

\section{Pendahuluan}

Undang-undang No. 33 Tahun 2014 tentang Jaminan Produk Halal (JPH) terhadap sadar halal para pelaku UMKM mulai diselenggarakan oleh pemerintah melalui Badan Penyelenggara Jaminan Produk Halal (BPJPH) Kementerian Agama. Hal ini sesuai dengan amanat UU No. 33 


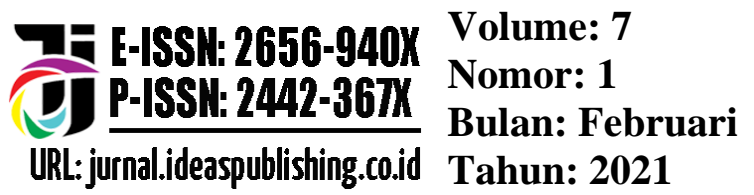

Tahun 2014 tentang JPH ditegaskan dalam pasal 3 dan pasal 4 UU No. 33 Tahun 2014 tentang Jaminan Produk Halal yaitu Pasal 3 berbunyi: Penyelenggaraan JPH bertujuan:

a. memberikan kenyamanan, keamanan, keselamatan, dan kepastian ketersediaan produk halal bagi masyarakat dalam mengonsumsi dan menggunakan produk; dan

b. meningkatkan nilai tambah bagi pelaku usaha untuk memproduksi dan menjual produk halal.

Pasal 4 berbunyi, "Produk yang masuk, beredar, dan diperdagangkan di wilayah Indonesia wajib bersertifikat halal".

Melihat amanat Undang-Undang di atas, Pemerintah Kota Gorontalo telah melakukan pemberlakukan kewajiban sertifikasi halal mulai 17 Oktober 2019 dan dilakukan secara bertahap. Tahap pertama, kewajiban ini akan diberlakukan terlebih dahulu kepada produk makanan dan minuman, serta produk jasa yang terkait dengan keduanya. Proses sertifikasi akan berlangsung mulai dari 17 Oktober 2019 sampai 17 Oktober 2024.

Tahap kedua, kewajiban sertifikasi akan diberlakukan untuk selain produk makanan dan minuman. Tahap kedua ini dimulai 17 Oktober 2021 dalam rentang waktu yang berbeda. Ada yang 7 tahun, 10 tahun, ada juga 15 tahun.

Badan Penyelenggara Jaminan Produk Halal (BPJPH) Kementerian Agama dibentuk tahun 2017 dan akan menggarap Penyelenggaraan Layanan Sertifikasi Halal (PLSH). BPJPH sedang mengembangkan sistem informasi halal atau (SIHalal). Pengajuan sertifikasi halal dari berbagai daerah bisa dilakukan secara online dan terkoneksi dengan pelaku kepentingan lain. Permohonan sertifikat halal harus dilengkapi dengan dokumen yaitu: data pelaku usaha, nama dan jenis produk, daftar produk dan bahan yang digunakan, serta proses pengolahan produk.

Permohonan sertifikat halal juga disertai dengan dokumen sistem jaminan halal. Pelaku usaha selanjutnya memilih Lembaga Pemeriksa Halal (LPH) sesuai dengan pilihan yang sudah disediakan. LPH saat ini ada LPPOM-MUI, maka pilihan pelaku usaha adalah LPPOM MUI pusat dan provinsi. Tahap selanjutnya, BPJPH melakukan verifikasi dokumen hasil pemeriksaan LPH. Hasil verifikasi itu kemudian disampaikan BPJPH kepada MUI untuk dilakukan penetapan kehalalan produk. MUI menetapkan kehalalan produk dalam sidang fatwa halal.

Dengan adanya UU Nomor 33 Tahun 2014 tentang Jaminan Produk Halal (JPH) terhadap sadar halal para pelaku UMKM, maka di tiap-tiap daerah harus melaksanakan undang-undang ini khususnya Provinsi Gorontalo. Terlebih lagi di Kota Gorontalo yang merupakan ibu kota provinsi, harus menjalani amanat UU No. 33 Tahun 2014 tentang Jaminan Produk Halal.

Berdasarkan kunjungan peneliti ke Kementerian Agama Kota Gorontalo yang diterima langsung oleh Bapak Syafwan, Kepala Seksi Tata Usaha dan beberapa staf. Kunjungan ini terkait dengan pengambilan data awal oleh peneliti melalui wawancara yang membahas terkait dengan efektifitas UU No. 33 Tahun 2014 tentang Jaminan Produk Halal yang berlaku efektif per 17 Oktober 2019 sejak diundangkan.

Menurut pihak Kemenag Kota Gorontalo bahwa berdasarkan peraturan menteri Agama RI bahwa setiap industri mamin (makanan dan minuman) wajib mendaftarkan produk halal sejak 17 Oktober 2019 sampai 17 Oktober 2024. Jika ada produsen pangan yang tidak mendaftarkan produknya hingga tahun 2024 maka izin usahanya dapat direkomendasikan untuk 


\section{Volume: 7 \\ Nomor: 1 \\ Bulan: Februari \\ Tahun: 2021}

E-ISSH: 2656-940X

P-ISSH: 2442-367K

URL: jurnal.ideaspublishing.co.id

ditutup. Adapun teknis yang berkaitan dengan pengajuan atau pendaftaran produk halal untuk makanan dan minuman (mamin) yaitu pihak produsen pangan atau UKM (Usaha Kecil Menengah) yang bergerak di bidang makanan dan minuman di Kota Gorontalo dapat mengunjungi Kementerian Agama Kota Gorontalo untuk pendaftaran pangan halal (Syafwan, 2019).

Pendaftaran pangan halal ditangani oleh satgas (satuan tugas) yang ada di bawah bidang Penyelenggaraan Syariah Kementerian Agama. Bidang ini bertugas melakukan pemeriksaan dokumen administrasi yang diajukan oleh produsen pangan, kemudian satgas meneruskannya kepada Kementerian Agama Kantor Wilayah Provinsi Gorontalo yang ditangani oleh BPJPH (Badan Penyelenggara Jaminan Produk Halal) yang akan kembali melakukan pemeriksaan teknis administratif. Kemudian diteruskan ke LPH (Lembaga Pemeriksa Halal) yang bersifat independen (dalam hal ini masih dilakukan oleh LPPOM MUI) untuk melakukan pemeriksaan bahan baku dan proses produksi makanan dan minuman yang dilakukan oleh produsen yang mengajukan pangan halal.

Hasil pemeriksaan laboratorium dari LPPOM MUI tersebut dijadikan landasan untuk dikeluarkan keputusan fatwa oleh Majelis Fatwa Majelis Ulama Indonesia (MUI) bahwa produk makanan dan minuman yang dihasilkan oleh produsen halal atau tidak. Jika halal, maka BPJPH bisa mengeluarkan sertifikat halal. Jika tidak halal, maka produsen dapat memperbaiki ulang yang terkait dengan standar mutu pangan halal yang ditetapkan seperti bahan baku dan proses pengolahannya.

Dulu, masa berlaku sertifikasi halal yang dikeluarkan MUI berlaku 2 tahun dan dapat diperpanjang lagi 3 bulan sebelum habis masa berlakunya. Saat ini, sertifikasi halal yang dikeluarkan oleh BPJPH Kemenag Provinsi berlaku 4 tahun dan dapat diperpanjang kembali dengan biaya Rp1.250.000.

Isu pangan halal sebagai isu yang menarik untuk terus dikaji mengingat konsumen masyarakat Indonesia khususnya Kota Gorontalo adalah mayoritas muslim yang setiap hari mengkonsumsi pangan. Berdasarkan hasil wawancara dengan kemenag ternyata pemerintah telah berupaya untuk memaksimalkan UU Nomor 33 Tahun 2014 tentang Jaminan Produk Halal. Akan tetapi masih banyak pelaku-pelaku usaha usaha mikro kecil dan menengah di Kota Gorontalo yang belum melaksanakan itu. Tentunya kesadaran masyarakat Kota Gorontalo masih sangat kurang sehingga peneliti mengambil judul Efektifitas UU No 33 Tahun 2014 tentang Jaminan Produk Halal (JPH) Terhadap Sadar Halal Para Pelaku UMKM di Kota Gorontalo.

\section{Metode}

Penelitian mengenai persoalan efektifitas undang-undang termasuk pada jenis penelitian empiris. Penelitian hukum sosiologis atau empiris yang mencakup penelitian terhadap identifikasi hukum dan efektifitas hukum" (Fajar dan Achnmad, 2010). Lokasi penelitian adalah Kota Gorontalo. Kota Gorontalo dipilih karena salah satu ibu kota provinsi yang paling banyak pelaku usaha mikro kecil dan menengahnya.

Jenis data yang digunakan adalah sebagai berikut.

1. Sumber data primer 


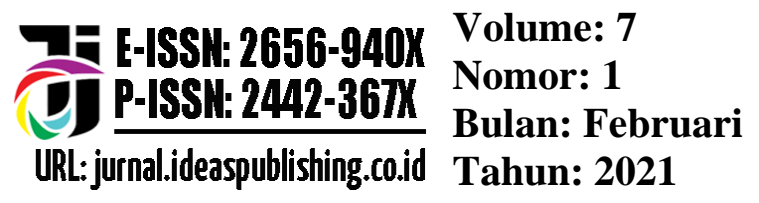

Sumber data primer adalah kata-kata dan tindakan orang yang diamati atau diwawancara. Pencatatan sumber data utama melalui pengamatan atau observasi dan wawancara yang merupakan hasil usaha gabungan dari kegiatan melihat, mendengar, dan bertanya yang dilakukan secara sadar dan terarah. Tujuannya untuk memperoleh informasi yang diperlukan dan diperoleh secara langsung dari responden yaitu para pelaku usaha mikro kecil dan menengah, Majelis Ulama Indonesia dan Kementrian Agama Kota Gorontalo.

2. Data sekunder

Data Sekunder berfungsi sebagai pelengkap atau pendukung data primer. Data ini bersumber dari literatur yaitu peraturan perundang-undangan dan dokumen-dokumen resmi yang berhubungan dengan efektifitas peraturan.

Peneliti menetapkan populasi dalam penelitian kali ini yaitu, para pelaku usaha mikro kecil dan menengah (UMKM) Kota Gorontalo. Mengingat persoalan tersebut cukup rumit, maka peneliti menetapkan sampel dan untuk sampel peneliti memilih sampel sebagai berikut.

1. Ketua Majelis Ulama Indonsia Kota Gorontalo;

2. Kepala Bagian Pemerintahan Kota Gorontalo;

3. Kepala Bagian Hukum Kota Gorontalo;

4. Kementrian agama Kota Gorontaalo

5. pelaku usaha mikro kecil dan menengah di Kota Gorontalo sebanyak 10 orang.

Teknik pengumpulan data dalam penelitian hukum empiris yang digunakan oleh peneliti, yaitu dengan melakukan wawancara dan pengambilan dokumentasi yang berhubungan dengan Efektifitas UU No. 33 Tahun 2014 tentang Jaminan Produk Halal (JPH) terhadap sadar halal para pelaku UMKM di Kota Gorontalalo.

Teknik analisis yang digunakan dalam penelitian ini adalah analisis data deskriptif. Analisis data deskriptif gambaran atau penamparan atas subjek dan objek penelitian yang dilakukannya. Peneliti tidak melakukan justifikasi atas hasil penelitiannya tersebut ( Fajar dan Achmad, 2010).

\section{Hasil dan Pembahasan}

Efektifitas UU No 33 Tahun 2014 tentang Jaminan Produk Halal (JPH) terhadap Sadar Halal para Pelaku Usaha Mikro Kecil dan Menengah di Kota Gorontalo (UMKM)

Setelah disetujui oleh Rapat Paripurna DPR-RI pada 25 September 2014, Rancangan UndangUndang Jaminan Produk Halal (JPH) telah disahkan oleh Presiden RI ke-6, Susilo Bambang Yudhoyono pada 17 Oktober 2014. Selanjutnya, pada hari yang sama, Menteri Hukum dan Hak Asasi Manusia (HAM) Kabinet Indonesia Bersatu (KIB) II Amir Syamsudin telah mengundangkan UU tersebut sebagai Undang-Undang Nomor 33 Tahun 2014 (diunduh https://ulahcopas.blogspot.com/rapat dalam Rapat Paripurna DPR-RI, 2019).

Dalam UU yang terdiri atas 68 pasal itu ditegaskan bahwa produk yang masuk, beredar, dan diperdagangkan di wilayah Indonesia wajib bersertifikat halal. Oleh karena itu, pemerintah bertanggung jawab dalam menyelanggarakan Jaminan Produk Halal (JPH).

Untuk pelaksanakan penyelenggaraan JPH, maka dibentuk Badan Penyelenggara Jaminan Produk Halal (BPJPH) yang berkedudukan di bawah dan bertanggung jawab kepada Menteri Agama. Jika diperlukan, BPJPH dapat membentuk perwakilan di daerah. Hal ini sesuai dengan 


\section{Volume: 7 \\ Nomor: 1 \\ Bulan: Februari \\ Tahun: 2021}

Pasal 5 Ayat (5) UU No. 33 Tahun 2014, yaitu "Ketentuan mengenai tugas, fungsi, dan susunan organisasi BPJPH diatur dalam Peraturan Presiden”.

Dalam penyelenggaraan Jaminan Produk Halal, BPJPH berwenang antara lain: merumuskan dan menetapkan kebijakan JPH, menetapkan norma, standar, prosedur, dan kriteria JPH, menerbitkan dan mencabut sertifikat halal pada produk luar negeri, melakukan registrasi sertifikat halal pada produk luar negeri (Peraturan Presiden dalam Pasal 5 Ayat 5 Undang-Undang Nomor 33 Tahun 2014).

Selain itu, UU ini menegaskan permohonan sertifikat halal diajukan oleh pelaku usaha secara tertulis kepada BPJPH. Selanjutnya, BPJPH menetapkan LPH untuk melakukan pemeriksaan dan/atau pengujian kehalalan produk. Pemeriksaan dan/atau pengujian kehalalan produk dilakukan oleh auditor halal di lokasi usaha pada saat proses produksi. Hal ini sesuai dengan bunyi Pasal 31 Ayat (3) Undang-Undang Nomor 33 Tahun 2014 yaitu "Dalam hal pemeriksaan produk sebagaimana dimaksud terdapat bahan yang diragukan kehalalannya. Dapat dilakukan pengujian di laboratorium."

Selanjutnya, LPH menyerahkan hasil pemeriksaan dan/atau pengujian kehalalan produk kepada BPJPH untuk disampaikan kepada Majelis Ulama Indonesia (MUI) guna mendapatkan penetapan kehalalan produk. MUI akan menggelar sidang fatwa halal untuk menetapkan kehalalan produk paling lama 30 (tiga puluh) hari kerja sejak diterimanya hasil pemeriksaan dan/atau pengujian produk dari BPJPH itu. Keputusan penetapan halal produk akan disampaikan MUI kepada BPJPH untuk menjadi dasar penerbitan sertifikat halal.

Keputusan kehalalan ada dua. Pertama, ketika dinyatakan tidak halal sesuai dengan bunyi pasal 34 Ayat (2) UU yaitu "Dalam hal Sidang Fatwa Halal menyatakan Produk tidak halal, BPJPH mengembalikan permohonan Sertifikat Halal kepada pelaku usaha disertai dengan alasan”. Kedua, ketika dinyatakan halal oleh Sidang Fatwa Halal MUI akan menjadi dasar BPJPH untuk menerbitkan Sertifikat Halal paling lama 7 (tujuh) hari kerja terhitung sejak keputusan kehalalan Produk diterima dari MUI. Pelaku usaha yang telah memperoleh Sertifikat Halal wajib mencantukam label halal pada: a. kemasan produk; b. bagian tertentu dari produk; dan/atau tempat tertentu pada produk. Hal ini sesuai dengan bunyi Pasal 39 Undang-Undang Nomor 33 Tahun 2014, yaitu "Pencantuman label halal harus mudah dilihat dan dibaca serta tidak mudah dihapus, dilepas, dan dirusak".

Sertifikat halal berlaku selama 4 (empat) tahun sejak diterbitkan oleh BPJPH. Sertifikat ini wajib diperpanjang oleh pelaku usaha dengan mengajukan pembaruan sertifikat paling lambat 3 (tiga) bulan sebelum masa berlaku sertifikat halal habis.

Di Provinsi Gorontalo khususnya Kota Gorontalo masih sangat lambat dalam mempraktikkan Undang-Undang Nomor 33 Tahun 2014. Terbukti kesadaran sebagian besar pelaku usaha mikro menengah masih banyak yang belum memiliki serifikat produk halal. Informasi ini berdasarkan hasil wawancara dengan pemilik usaha mikro menengah di Kota Gorontalo. Mereka sudah mengetahui tentang adanya sertifikasi halal. Hal ini berasal dari informan berinisial OC yang diwawancarai. Pengetahuan tentang sertifikasi halal di kalangan pemilik usaha mikro di Kota Gorontalo hanya sebatas tahu saja secara umum dan tidak spesifik. Artinya pengetahuan meraka kurang terhadap sertifikasi ini. 


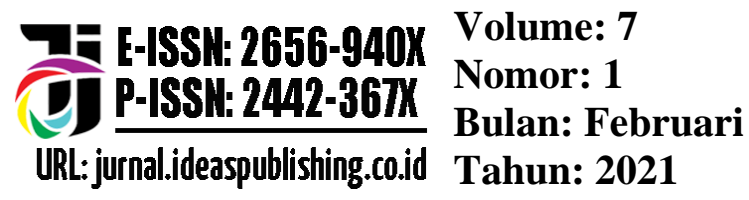

Pengetahuan yang baik mengenai suatu hal akan mempermudah penerapan suatu ilmu yang dipelajarinya. Sedangkan jika pengetahuan kurang terhadap suatu hal, maka jelas akan ada kendala dalam pelaksanaannya. Inilah yang terjadi di kalangan pemilik usaha mikro menengah di Kota Gorontalo. Pengetahuan mereka kurang mengenai sertifikasi halal sehingga untuk menerapkannya terasa sulit.

Untuk mendapatkan sertifikasi halal, pelaku usaha harus melakukan prosedur-prosedur yang telah ditetapkan. Prosedur tersebut diajukan dan digunakan untuk mendapat sertifikasi halal. Pada kenyataannya pemilik usaha mikro menengah di Kota Gorontalo yang telah diwawancarai tidak ada satu pun yang mengetahui prosedur tersebut. Artinya, selain pengetahuan yang kurang, kesadaran pemilik usaha dalam mengajukan sertifikasi halal kurang baik. Hal ini disebabkan kesibukan mengurus usaha mereka yang membuat para pemilik usaha lupa. Apalagi ketika pengunjung mereka ramai serta sibuk memikirkan aspek bisnis usaha mereka. Dikatakan oleh salah satu pemilik usaha di Kota Gorontalo beliau siap melakukan sertifikasi halal asal tidak mondar-mandir dalam melakukan pengurusan dan langsung didaftarkan untuk mendapatkan sertifikasi.

Sangat disayangkan untuk saat ini di Kota Gorontalo belum ada usaha mikro menengah yang bersertifikat halal. Hal ini diungkapkan oleh informan dari semua pemilik usaha mikro menengah dengan pertanyaan yang peneliti ajukan "Apakah ada usaha mikro menengah makanan minuman yang sudah memiliki Sertikikat Halal?” Hampir semua informan menjawab tidak ada., karena salah satu informan mengungkapkan bahwa pemilik usaha yang sudah memiliki sertifikat halal di Gorontalo hanya KFC.

Sejalan dengan ungkapan dari para pemilik Usaha, Ibu Ros selaku pegawai Dinas Perdagangan juga memberikan keterangan yang sama tentang sertifikasi halal yang ada di Kota Gorontalo. Beliau mengatakan: "Memang benar di Kota Gorontalo belum ada yang tersertifikasi halal pada usaha warung makanan dan minumannya, yang ada hanya label. Itu pun hanya bisa dihitung dengan jari seperti roti, air minum mineral, dan keripik saja (Pegawai Kantor Perdagangan Kota Gorontalo, 2019).

Pengetahuan serta kesadaran dari pemilik Usaha di Kota Gorontalo yang masih lemah sehingga penerapan sertifikasi halal warung makan di Kota Gorontalo khususnya pemilik usaha warung makan tidak berjalan. Kemudian dari data yang didapatkan menunjukkan bahwa jangankan persoalan tentang sertifikasi halal, untuk mengurus surat izin usaha saja pemilik warung atau pemilik usaha lainnya banyak yang tidak mendaftarkan usahanya dengan jelas, padahal administrasi tentang usaha yang dijalankan sangat penting karena mendapat kejelasan serta dapat dilindungi jika terjadi hal yang tidak diinginkan. Hal tersebut berarti tingkat kesadaran dan kepedulian terhadap sertifikasi halal pemilik warung atau usaha yang ada di Kota Gorontalo sangat kurang, terbukti dengan urusan yang sangat penting dalam membuka sebuah usaha banyak yang tidak mendaftar.

"Penting diketahui oleh masyarakat bahwa sertikikasi halal sudah memiliki payung hukum yang jelas dan telah disahkan oleh Dewan Perwakilan Rakyat pada tanggal 25 September 2014 yaitu Undang-Undang No. 33 tahun 2014 tentang Jaminan Produk Halal" (Panji Adam, 2017 hlm. 10). Undang-undang ini memperkuat dan mengatur berbagai regulasi halal yang selama ini tersebar dan dapat disebut sebagai payung hukum bagi pengaturan produk 


\section{Volume: 7 \\ Nomor: 1 \\ Bulan: Februari \\ Tahun: 2021}

E-ISSH: 2656-940X

P-ISSH: 2442-367K

URL: jurnal.ideaspublishing.co.id

halal. Jaminan produk halal ini mencakup berbagai aspek tidak hanya obat, makanan, dan kosmetik, akan tetapi lebih luas dari itu mencakup produk kimia, biologi, rekayasa genetik, serta barang yang digunakan dan dimanfaatkan oleh masyarakat.

Proses produk halal (PPH) sebagai rangkaian kegiatan untuk menjamin kehalalan produk mencakup penyediaan bahan, pengelolaan, penyimpanan, pengemasan, pendistribusian, penjualan, dan penyajian produk. Namun, sertifikasi halal pada saat ini bukan sebagai suatu kewajiban bagi para pelaku usaha, akan tetapi hanya bersifat sukarela. Artinya LPPOM MUI memberikan sertifikasi halal kepada pelaku usaha yang mendaftarkan warung makan atau produk untuk diaudit. Padahal dengan melakukan sertifikasi halal akan meningkatkan daya saing dalam kompetensi hasil produksi pelaku usaha.

Kendala dalam Penerapan UU No. 33 Tahun 2014 tentang Jaminan Produk Halal (JPH) Terhadap Sadar Halal Para Pelaku Usaha Mikro Kecil dan Menegah di Kota Gorontalo (UMKM)

\section{Kurangnya Kesadaran tentang Kehalalan Pelaku Usaha Masyarakat Kota Gorontalo}

Kesadaran pelaku usaha masyarakat Kota Gorontalo adalah kemampuan untuk merasakan secara sadar akan kejadian dan objek pemahaman. Persepsi terhadap kejadian atau subjek dapat juga diartikan sebagai suatu konsep kesadaran. Kesadaran kehalalan merupakan suatu yang diketahui berdasarkan mengerti tidaknya seorang muslim khususnya di Kota Gorontalo yang disebut sebagai serambi Madinah. Seharusnya, Kota Gorontalo memiliki lebih besar kesadaran tentang kehalalan. Seperti, mengetahui proses penyembelihan yang benar dan memprioritaskan makanan halal untuk dikonsumsi.

Faktor yang menjadi indikator kesadaran konsumen dalam memilih produk halal adalah sebagai berikut.

1. Bahan baku halal

Bahan baku halal merupakan salah satu faktor penting yang harus konsumen pahami. Seorang konsumen dalam memilih produknya wajib memiliki pengetahuan atas komposisi bahan baku yang digunakan untuk memastikan kehalalan suatu produk.

2. Kewajiban agama

Kehalalan suatu produk menjadi prioritas serta kewajiban bagi konsumen muslim dalam menjalankan ketaatan pada agamanya. Oleh sebab itu, kewajiban untuk mengkonsumsi produk halal menjadi salah satu tolok ukur dari kesadaran halal konsumen muslim.

3. Proses produksi

Salah satu indikator dari kesadaran halal adalah pengetahuan akan kehalalan proses produksi. Pengetahuan proses produksi dapat diketahui melalui televisi ataupun media internet.

4. Kebersihan produk

Kebersihan produk merupakan salah satu tolok ukur dari kesadaran halal yang dapat langsung kita cermati pada produk.

5. Pengetahuan produk halal internasional

Kesadaran halal akan suatu produk tidak hanya sebatas memahami produk yang terdapat di dalam negeri saja, lebih-lebih produk yang beredar di pasaran tidak hanya produk dari 


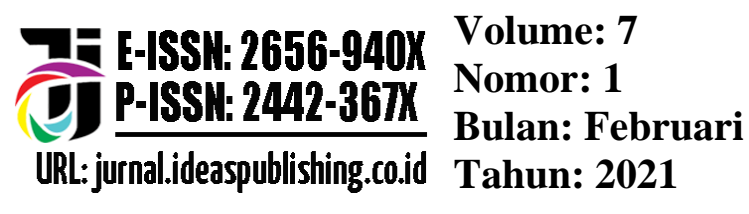

dalam negeri melainkan produk luar negeri pun telah banyak beredar dipasaran. Oleh karena itu, pengetahuan akan adanya produk yang berasal dari luar negeri menjadi salah satu indikator dalam kesadaran halal.

Menurut penjelasan Bapak Syafwan selaku Ketua Kanwil Agama Gorontalo telah berupaya semaksimal mungkin dalam menerapkan UU No. 33 Tahun 2014 khususnya di tahun 2019. Upaya ini juga dengan dikeluarkannya peringatan kepada para pelaku usaha mikro kecil dan menengah dengan mencabut surat izin usaha dari pelaku usaha. Namun, kesadaran masyarakat Gorontalo masih sangat kurang. Hal ini dibuktikan dengan data tiga tahun terakhir yaitu sebagai berikut.

\begin{tabular}{|l|l|c|}
\hline No. & Tahun & Pendaftar \\
\hline 1. & 2018 & 1 Pendaftar \\
\hline 2. & 2019 & 5 Pendaftar \\
\hline 3. & 2020 & 11Pendaftar \\
\hline
\end{tabular}

Melihat data di atas bahwa pendaftar pelaku usaha masih sangat sedikit dibandingkan dengan pelaku usaha yang kita lihat di lapangan. Untuk itu dapat disimpulkan bahwa kesadaran masyarakat Kota Gorontalo masih sangat kurang.

\section{Pentingnya Mengurus Sertifikasi Halal}

Sertifikasi halal adalah jaminan keamanan bagi umat Islam untuk dapat mengonsumsi produk makan sesuai ajaran Islam. Fatwa MUI yang menyatakan kehalalan suatu produk sesuai dengan syari'at Islam yang disebut juga dengan sertifikasi halal. Sertifikasi halal merupakan syarat untuk mendapatkan izin pencantuman label halal pada kemasan produk dari instansi pemerintah yang berwenang yang dinyatakan oleh Direktori Produk Halal Indonesia. Sertifikasi halal juga menandakan sebagai proses pemeriksaan secara rinci terhadap kehalalan produk yang pada akhirnya diputuskan kehalalannya dalam bentuk fatwa MUI. Produk yang telah lolos uji sertifikasi halal oleh MUI dapat dibuktikan dengan adanya logo halal yang tercantum dalam kemasan produk.

Pentingnya sertifikat halal sebagaimana yang telah diuraikan di atas. Namun, pada kenyataannya masyarakat Kota Gorontalo tidak memperhatikan hal tersebut. Padahal masyarakat Kota Gorontalo sebagian besar penduduknya adalah umat muslim yang sudah semestinya harus memiliki label halal karena untuk keamanan dan kenyamanan pembeli.

Sebagaimana hasil wawancara dengan lima orang pelaku usaha mikro kecil yang ada di Jalan Agus Salim Kota Tengah, Kota Gorontalo. Dari kelima pelaku usaha ini dapat disimpulkan bahwa kendala yang mereka hadapi adalah sebagai berikut.

1. Sulitnya dalam mengurus sertifikasi halal membuat mereka tidak melakukan pengurusan dengan alasan banyak persyaratan yang harus dilengkapi.

2. Kurangnya pengawasan dari pemerintah sehingga membuat mereka berpikir bahwa hal ini tidak penting.

3. Ada dua orang pelaku usaha yang sama sekali tidak mengetahui sertifikasi halal.

4. Tidak berbanding lurus dengan pendapatan mereka, karena mengurus sertifikasi halal banyak proses administrasi yang harus pelaku usaha bayarkan ke pemerintah. 


\section{Volume: 7 \\ Nomor: 1 \\ Bulan: Februari \\ Tahun: 2021}

E-ISSH: 2656-940X

P-ISSH: 2442-367K

URL: jurnal.ideaspublishing.co.id

5. Lebih nyaman dengan keadaan tidak mengurus, karena pemerintah tidak pernah memperhatikan mereka. Jadi menurut mereka tidak perlu repot untuk mengurus sertifikasi halal (Pelaku Usaha Mikro Kecil Kota Gorontalo, 2020).

\section{Kurangnya Peran dari Pemerintah dalam Memberikan Perlindungan Terhadap Konsumen}

Terbitnya Undang-Undang Nomor 8 tahun 1999 tentang Perlindungan Konsumen, ternyata tidak serta-merta membuat para konsumen di Indonesia menjadi terlindungi dari oknum pelaku usaha yang tidak bertanggung jawab. Dalam pasal 1 ayat (1) Undang-Undang Nomor 8 Tahun 1999 tentang Perlindungan Konsumen disebutkan bahwa:

"perlindungan konsumen adalah segala upaya yang menjamin adanya kepastian hukum untuk memberi perlindungan kepada konsumen”.

Dalam hal ini pemerintah memberikan kepastian hukum bagi para konsumen yang haknya dilanggar, antara lain baru sebatas menerima pengaduan dari masyarakat atau pelaku usaha, memberikan advokasi dan edukasi, serta saran dan rekomendasi kepada pemerintah, antara lain seperti menegur pelaku usaha yang merugikan konsumen.

Pemerintah Kota Gorontalo harus memberikan perlindungan konsumen mengingat perkembangan teknologi dan transaksi perdagangan menuntut adanya penataan ulang. Khususnya terkait dengan masalah perlindungan konsumen yang saat ini tersebar di berbagai sektor.

Berbagai masalah atau temuan kasus terus muncul terkait perlindungan konsumen. Angkanya pun meningkat. Seharusnya pemerintah Kota Gorontalo bertindak tegas karena menyangkut dengan UU perlindungan konsumen yaitu minimal dengan memberikan denda terhadap pelaku usaha yang sering tidak memiliki label halal. Hal ini harus dimulai dengan pelaku-pelaku usaha kecil yang sering beredar di mana-mana. Mereka harus mendapatkan dan memiliki label halal. Hal ini dilakukan karena menyangkut keamanan dan kenyamanan barang yang dijual kepada konsumen apalagi masyarakat Kota Gorontalo dikenal dengan mayoritas Islam yang tinggi.

Perlindungan konsumen di Indonesia khusus di Kota Gorontalo seharusnya BPKN memberikan saran dan rekomendasi kepada pemerintah dalam rangka penyusunan kebijakan di bidang perlindungan konsumen. Sudah seharusnya dalam UU Perlindungan Konsumen berisi acuan dalam memberikan sanksi kepada pelaku usaha yang terbukti melanggar dalam hal ini karena tidak memilki izin serta label halal dalam membuka usaha. Pelanggaran-pelanggaran tersebut, bahkan seharusnya sampai pada level pelanggaran kecil, namun merugikan konsumen.

Kesadaran konsumen di Indonesia terbilang masih rendah. Berdasarkan Indeks Keberdayaan Konsumen (IKK) pada 2019, hanya sebesar 30,86 persen. IKK merupakan instrumen untuk mengukur kesadaran dan pemahaman konsumen akan hak dan kewajibannya, serta kemampuannya dalam berinteraksi dengan pasar. Jika dibandingkan dengan negaranegara di Eropa, IKK sudah mencapai 51 persen. Penyebab rendahnya IKK di Indonesia dipicu minimnya masyarakat soal regulasi, dan lembaga terkait perlindungan konsumen, serta perilaku komplain yang belum umum di kalangan konsumen Indonesia khususnya di Kota Gorontalo. 


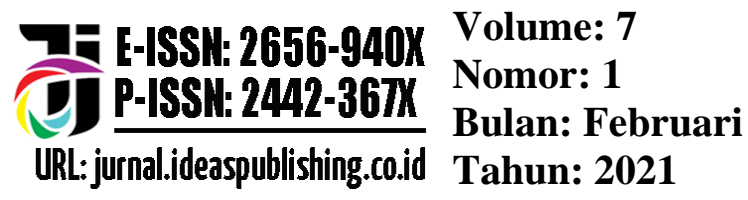

\section{Simpulan}

Proses produk halal (PPH) sebagai rangkaian kegiatan untuk menjamin kehalalan produk mencakup penyediaan bahan, pengelolaan, penyimpanan, pengemasan, pendistribusian, penjualan, dan penyajian produk. Namun, sertifikasi halal pada saat ini bukan sebagai suatu kewajiban bagi para pelaku usaha akan tetapi hanya bersifat sukarela. Artinya LPPOM MUI memberikan sertifikasi halal kepada pelaku usaha yang mendaftarkan warung makan atau produk untuk diaudit. Padahal dengan melakukan sertifikasi halal akan meningkatkan daya saing dalam kompetensi hasil produksi pelaku usaha. Dalam penelitian ini juga penulis dapat menyimpulkan kendala dalam penerapan UU Nomor 33 tahun 2014 tentang Jaminan Produk Halal (JPH) terhadap sadar halal para pelaku usaha mikro kecil menengah (UMKM)dan mengah di Kota Gorontalo yakni kurang kesadaran para pelaku UMKM mengenai pentingnya sertifikat halal. Selanjutnya yang menjadi kendala efektifitasnya undang-undang ini yakni kurangnya peran pemerintah Kota Gorontalo. Pemerintah harus memberikan perlindungan bagi konsumen. Berbagai masalah atau temuan kasus terus muncul terkait perlindungan konsumen dan angkanya pun meningkat. Seharusnya pemerintah Kota Gorontalo bertindak tegas karena menyangkut dengan UU perlindungan konsumen yaitu minimal dengan memberikan denda terhadap pelaku usaha yang sering tidak memiliki label halal. Hal ini harus dimulai dengan pelaku-pelaku usaha kecil yang sering beredar di mana-mana harus mendapatkan dan memilki label halal.

\section{Daftar Rujukan}

Doholio, A. M. (2011). Efektifitas 3 Peraturan Bupati Nomor 9 Tahun 2010 tentang Tugas dan Fungsi Kantor Polisi Pamong Praja dalam Rangka Penegakan Peraturan Daerah di Kecamatan Lemito Pohuwato.

Fajar, M. dan Achnmad, Y. (2010). Dualisme Penelitian Hukum. Normatif dan Empiris. Yogyakarta: Pustaka Pelajar.

Undang-Undang Nomor 33 Tahun 2014

Undang-Undang Nomor 8 tahun 1999

https://ulahcopas.blogspot.com/rapat paripurna Dpr Ri-administrasi-produk-halal.html 